\title{
Aflatoxins in Food and Feed: An Overview on Prevalence, Detection and Control Strategies
}

\author{
Dipendra K. Mahato ${ }^{1 \dagger}$, Kyung Eun Lee ${ }^{2 \dagger}$, Madhu Kamle ${ }^{3 *}$, Sheetal Devi ${ }^{4}$, \\ Krishna N. Dewangan ${ }^{\text {, }}$ Pradeep Kumar ${ }^{3 *}$ and Sang G. Kang ${ }^{2 *}$
}

${ }^{1}$ School of Exercise and Nutrition Sciences, Deakin University, Burwood, VIC, Australia, ${ }^{2}$ Molecular Genetics Laboratory, Department of Biotechnology, Yeungnam University, Gyeongsan, South Korea, ${ }^{3}$ Department of Forestry, North Eastern Regional Institute of Science and Technology, Nirjuli, India, ${ }^{4}$ SAB Miller India Ltd., Sonipat, India, ${ }^{5}$ Department of Agricultural Engineering, North Eastern Regional Institute of Science and Technology, Nirjuli, India

\section{OPEN ACCESS}

Edited by:

Federica Giacometti,

University of Bologna, Italy

Reviewed by:

Shihua Wang,

Fujian Agriculture and Forestry

University, China

Daniela Jakšić,

University of Zagreb, Croatia

*Correspondence:

Madhu Kamle

madhu.kamle18@gmail.com

Pradeep Kumar

pkbiotech@gmail.com

Sang G. Kang

kangsg@yu.ac.kr

${ }^{\dagger}$ These authors have contributed equally to this work

Specialty section:

This article was submitted to

Food Microbiology,

a section of the journal

Frontiers in Microbiology

Received: 07 July 2019

Accepted: 17 September 2019

Published: 04 October 2019

Citation:

Mahato DK, Lee KE, Kamle M,

Devi S, Dewangan KN, Kumar $P$ and

Kang SG (2019) Aflatoxins in Food

and Feed: An Overview on

Prevalence, Detection and Control

Strategies. Front. Microbiol. 10:2266.

doi: 10.3389/fmicb.2019.02266
Aflatoxins produced by the Aspergillus species are highly toxic, carcinogenic, and cause severe contamination to food sources, leading to serious health consequences. Contaminations by aflatoxins have been reported in food and feed, such as groundnuts, millet, sesame seeds, maize, wheat, rice, fig, spices and cocoa due to fungal infection during pre- and post-harvest conditions. Besides these food products, commercial products like peanut butter, cooking oil and cosmetics have also been reported to be contaminated by aflatoxins. Even a low concentration of aflatoxins is hazardous for human and livestock. The identification and quantification of aflatoxins in food and feed is a major challenge to guarantee food safety. Therefore, developing feasible, sensitive and robust analytical methods is paramount for the identification and quantification of aflatoxins present in low concentrations in food and feed. There are various chromatographic and sensor-based methods used for the detection of aflatoxins. The current review provides insight into the sources of contamination, occurrence, detection techniques, and masked mycotoxin, in addition to management strategies of aflatoxins to ensure food safety and security.

\section{Keywords: human health, outbreaks, aflatoxins contamination, detection, food and feed}

\section{INTRODUCTION}

Food safety and security are among the major problems in the current climate of increasing population. These are mainly determined by three key aspects viz., (i) enough food availability, (ii) access to safe food and (iii) utilization of the food in terms of quality, nutritional and cultural purposes for a healthy life (FAO, 1996). The failure of any of these aspects leads to food insecurity and malnutrition that further influences human health, in addition to the socio-economic aspect of society. In addition, food and feed contamination by mycotoxins are one of the key factors responsible for creating food insecurity (Udomkun et al., 2017).

As per the Food and Agriculture Organization (FAO), one-fourth of the world's crop is affected by mycotoxins ( $\mathrm{Wu}, 2007$; Pankaj et al., 2018). The three main genera of fungi producing mycotoxins are Aspergillus, Fusarium, and Penicillium (Reddy et al., 2010). Among various type of 
mycotoxins, aflatoxins (AFs) are highly toxic and are known to contaminate a wide variety of foods such as maize, groundnuts, dried fruits, meat and milk-based products (Mutegi et al., 2009; Perrone et al., 2014; Iqbal et al., 2015). AFs are produced by Aspergillus species, namely A. flavus, A. nomius and A. parasiticus (Payne and Brown, 1998), in addition to its production by other species of Aspergillus like A. astellatus (Reiter et al., 2009). These fungi usually grow in the warm and humid conditions of tropical and subtropical regions (Magan and Aldred, 2007; Battilani et al., 2011). Food processing techniques are not sufficient to eliminate AFs from contaminated food and feed due to their heat resistant nature (Medina et al., 2017b).

The ingestion of AFs from contaminated food and feed has led to serious health complications in humans and animals (Fung and Clark, 2004; Binder et al., 2007; Sherif et al., 2009). Therefore, different countries have implemented strict regulations for AFs in food and feed to maintain the health of individuals (Juan et al., 2012). The safe limit of AFs lies in the range of $4-30 \mu \mathrm{g} / \mathrm{kg}$ for human consumption. The European Union has the strictest standard level with AFB1 and total AFs not beyond $2 \mu \mathrm{g} / \mathrm{kg}$ and $4 \mu \mathrm{g} / \mathrm{kg}$, respectively, in any product meant for direct consumption (EC, 2007, 2010). Similarly, the maximum acceptable limit set for AFs in the United States is $20 \mu \mathrm{g} / \mathrm{kg}$ ( $\mathrm{Wu}, 2006)$. Besides this, various innovative technologies and control strategies are applied for pre- and post-harvest management of AFs to enhance sustainable agricultural productivity (Prietto et al., 2015). Though there are numerous publications on AFs in food and feed, the novelty and strength of this review lie with the enlistment of the new methods developed for AFs detection in food and feed with special reference to masked AFs. In addition, the review also focuses on the occurrence, impact of climate change along with the control strategies of AFs in food and feed to ensure food safety and security for healthy living and socioeconomic development.

\section{OCCURRENCE OF AFLATOXINS IN FOOD AND FEED}

Aflatoxins are chemically difuranocoumarin derivatives with a bifuran group attached to the coumarin nucleus and a pentanone ring (in case of AFBs) or a lactone ring (in case of AFGs) (Schuda, 1980). The four major AFs among the identified 20 are AFB1, AFB2, AFG1 and AFG2. The B-types are produced by A. flavus while G-types are produced by A. parasiticus (Kumar et al., 2017). The biosynthesis of AFs consists of 18 enzymatic steps with at least 25 genes responsible for producing the enzymes and regulating the biosynthetic process (Yu et al., 2002; Yabe and Nakajima, 2004).

The occurrence of AFs is common in wide varieties of food and feed (Table 1). Some of the most affected food and feed include peanuts, nuts, figs, corn, rice, spices and dried fruits (Martinez-Miranda et al., 2019). It has been shown that among the tested cereals, $37.6 \%$ were at least contaminated by any of the AFs (Andrade and Caldas, 2015). Though rice is not the highrisk commodity for AFs contamination, but AFB1 besides other mycotoxins have been detected in rice from China, Egypt, India, Iran, Malaysia, Nepal, Pakistan, Philippines, United Kingdom and United States (Tanaka et al., 2007; Rahmani et al., 2011; Lutfullah and Hussain, 2012). Therefore, AFs pose serious health issues by their ingestion from contaminated food and feed or by carryover AFs in them (Nordkvist et al., 2009; Reiter et al., 2010).

AFB1, as a potent carcinogen to humans, is associated with serious health complications (IARC, 2012). It has been a causal factor for liver cancer and acute hepatitis as well as periodic outbreaks of acute aflatoxicosis leading to death (AzzizBaumgartner et al., 2005) as reported with lethal aflatoxicosis in Kenya (Probst et al., 2007). AFs are mostly detoxified in the liver which is the reason why liver cancer is rare. After the ingestion of AFB1, a series of metabolic processes converts it to an active intermediate, AFB1-exo-8,9-epoxide, by cytochrome P450 enzymes. The detoxification reaction occurs in conjugation with glutathione transferases (GSTs). The detoxification mechanism of AFB1-exo-8,9-epoxide might be linked to the mechanism that prevents liver cancer, however, it is not yet fully revealed (Guengerich et al., 1998). Unfortunately, on the other hand, the food and feed contamination by AFs is a persistent problem worldwide. The outbreaks due to AFs are more prone in tropical and subtropical areas, with a few in temperate regions (like the United States Midwest). In addition, the Mediterranean zones have become prone to AFs contamination due to shifting in traditional occurrence areas of AFs because of climate change i.e., increase in average temperatures, $\mathrm{CO}_{2}$ levels and rainfall patterns (Marasas et al., 2008). This has led to an increase in contamination of crops with fungi and AFs worldwide.

\section{CROPS AFFECTED BY AFLATOXINS}

Cereals and cereal-based products are the major foods for human consumption worldwide (Temba et al., 2017). Among cereals, rice and corn are mostly contaminated by AFs in natural conditions due to changes in agricultural practices. The AFs are produced both in pre- and post-harvest conditions (Hesseltine, 1974). Filazi and Sireli (2013) reported rice to be more prone to AFs contamination as compared to other cereals. The fungal growth occurs due to improper drying of rice grains retaining higher moisture content $(>14 \%)$. As a result, these fungi cause discoloration of grain and/or husk along with deteriorating the quality of the grains. Groundnut and beans, on the other hand, are frequently used in many African diets to supplement cereal diets (Soro-Yao et al., 2014). However, these are highly prone to AFs contamination both in field and storage conditions (Lombard, 2014). The extent of fungal growth and AFs production in cereals depends on temperature, moisture, soil type, and storage conditions (Achaglinkame et al., 2017). In addition, spices are susceptible to AFs contamination and are significantly affected by storage and processing conditions. Elshafie et al. (2002) reported the AFs contamination in a wide variety of spices including black pepper, cardamom, cinnamon, clove, cumin, coriander, and ginger in the Sultanate of Oman. Furthermore, Tchana et al. (2010) reported the presence of AFs in eggs collected from a poultry farm and in raw cow milk in 
TABLE 1 | Occurrence of Aflatoxins in food and feed around the world.

\begin{tabular}{|c|c|c|c|c|c|}
\hline Country & Food matrix & Aflatoxin & Range $(\mu \mathrm{g} / \mathrm{kg})$ & Detection technique & References \\
\hline Turkey & Almond & AFB1 & $1-13$ & TLC & Gürses, 2006 \\
\hline Turkey & Butter & AFM1 & $<0.001-0.100$ & ELISA & Aycicek et al., 2005 \\
\hline Brazil & Cashew nuts & Total AFs & $0.60-31.50$ & ELISA & Milhome et al., 2014 \\
\hline United States & Chilies & AFB1 & $<2$ & ELISA and TLC & Singh and Cotty, 2017 \\
\hline Costa Rica & Corn & Total AFs & 24 & ELISA and HPLC & Granados-Chinchilla et al., 2017 \\
\hline Zimbabwe & Corn & AFB1 & $0.75-26.6$ & HPLC & Murashiki et al., 2017 \\
\hline India & Corn & AFB1 & $48-383$ & HPLC & Mudili et al., 2014 \\
\hline Serbia & Corn & Total AFs & $1.01-86.10$ & ELISA & Kos et al., 2013 \\
\hline Vietnam & Corn & AFB1 & $1.0-34.80$ & ELISA & Lee et al., 2017 \\
\hline Turkey & Cream cheese & AFM1 & $0.1-0.70$ & ELISA & Yaroglu et al., 2005 \\
\hline Pakistan & Dried Fruits & AFB1 & $0.04-9.80$ & HPLC & Masood et al., 2015 \\
\hline Turkey & Feed & AFB1 & $0-5$ & LCMS/MS & Yalcin et al., 2017 \\
\hline Turkey & Figs & Total AFs & $0.1-28.20$ & HPLC & Kabak, 2016 \\
\hline Nigeria & Ginger & Total AFs & $0.11-9.52$ & HPLC & Lippolis et al., 2017 \\
\hline Ethiopia & Groundnuts & Total AFs & $15-11,900$ & HPLC & Chala et al., 2013 \\
\hline Turkey & Hazelnut & AFB1 & $0.07-43.60$ & HPLC & Baltaci et al., 2012 \\
\hline Serbia & Infant formula & AFM1 & $<0.03-0.02$ & HPLC & Torović, 2015 \\
\hline Turkey & Lentil & AFB1 & $0.57-1.74$ & HPLC & Baydan et al., 2016 \\
\hline Turkey & Maize flour & AFB1 & $0.041-1.12$ & HPLC & Kara et al., 2015 \\
\hline Egypt & Meat products & Total AFs & $0.47-2.10$ & Fluorimeter & Abd-Elghany and Sallam, 2015 \\
\hline Greece & Milk & AFM1 & $<0.005-0.02$ & ELISA & Tsakiris et al., 2013 \\
\hline Iran & Milk (cow) & AFM1 & $0.006-0.18$ & HPLC & Bahrami et al., 2016 \\
\hline Brazil & Milk (cow) & AFM1 & 0.05 & HPLC & Picinin et al., 2013 \\
\hline Italy & Milk (cow/buffalo) & AFM1 & 0.004 & HPLC & De Roma et al., 2017 \\
\hline Portugal & Milk (cow) & AFM1 & $0.005-0.07$ & ELISA & Duarte et al., 2013 \\
\hline Japan & Nuts & AFB1 & $0.17-2.59$ & HPLC, HPTLC & Kumagai et al., 2008 \\
\hline Saudi Arabia & Nuts & Total AFs & $1.0-110$ & HPLC & Neamatallah and Serdar, 2013 \\
\hline Malawi & Nut-based foods & AFB1 & $0.1-40.60$ & HPLC & Matumba et al., 2014 \\
\hline Zambia & Peanuts & AB1 & $0.015-46.60$ & HPLC & Bumbangi et al., 2016 \\
\hline Taiwan & Peanut products & Total AFs & $0.2-513.40$ & HPLC & Chen et al., 2013 \\
\hline Turkey & Red-chili powder & AFB1 & $0.025-40.90$ & ELISA & Aydin et al., 2007 \\
\hline China & Rice & AFB1 & $0.03-20$ & HPLC & Lai et al., 2015 \\
\hline India & Rice & AFB1 & $0.1-308$ & Indirect competitive (icELISA) & Reddy et al., 2009 \\
\hline Pakistan & Rice & AFB1 & $0.04-21.30$ & HPLC & lqbal et al., 2016 \\
\hline China & Rice & AFB1 & $0.1-136.80$ & HPLC & Sun et al., 2011 \\
\hline Tunisia & Sorghum & AFB1 & $0.4-25.1$ & HPLC & Ghali et al., 2010 \\
\hline Italy & Spices & AFB1 & $0.59-5.38$ & HPLC & Prelle et al., 2014 \\
\hline Malaysia & Spices & AFB1 & $0.58-4.64$ & ELISA & Reddy et al., 2011 \\
\hline Tunisia & Wheat & AFB1 & $0.12-18$ & HPLC & Ghali et al., 2010 \\
\hline Malaysia & Wheat & AFB1 & $0.55-5.07$ & ELISA & Reddy et al., 2011 \\
\hline China & Yogurt & AFM1 & 0.05 & HPLC & Guo et al., 2013 \\
\hline Iran & Yogurt & AFM1 & $0.006-0.021$ & HPLC & Bahrami et al., 2016 \\
\hline
\end{tabular}

Cameroon. Hence, the affected crops allow AFs to enter the food chain, which is very much influenced by the climatic conditions.

\section{IMPACT OF CLIMATE CHANGE ON AFLATOXIN PRODUCTION}

Climate change significantly impacts on the quality and availability of staple foods for consumption. With the increasing population worldwide, a major emphasis has been put on the safety of food and feed that can address the increasing demand with the increase in the yields by protecting the crops from adverse climatic conditions (Medina et al., 2017a). Aflatoxins contamination has affected millions of hectares of maize and peanut crops in the United States (Robens and Cardwell, 2003). Maize is a staple food for people living in warm climates throughout Asia, Africa, and the Americas, which are prone to the influences of climate change (Lewis et al., 2005). The change in climate simultaneously impacts the complex communities of AF-producing fungi by altering the number 
of AF-producers to change its fungal community's structure. Aflatoxins contamination occurs via an initial phase during crop development and a second phase during crop maturation. The contamination is greater in warm, humid, and even hot deserts and drought conditions (Cotty and Jaime-Garcia, 2007).

A. flavus has highly evolved physiological mechanisms to acclimatize to adverse climatic conditions and dominates other fungal species (Nesci et al., 2004; Magan, 2007). Climate change alters the temperature and water activity $\left(\mathrm{a}_{\mathrm{w}}\right)$ in the environment which further influences the gene expression to produce AFs. The conditions of temperature and $\mathrm{a}_{\mathrm{w}}$ regulate the extent of fungal growth and AFs production (Schmidt-Heydt et al., 2009; Schmidt-Heydt et al., 2010). The AF-producing genes are grouped on the genome and express the main regulatory genes (aflR; aflS), as well as structural genes (aflD) which are influenced by the interaction of temperature $\times a_{w}$ conditions. As revealed by Schmidt-Heydt et al. (2010), the expression proportion of aflR/aflS significantly correlates with the amount of AFB1 produced. In addition, the expression of sugar transporter genes was significantly affected by the condition of temperature and $\mathrm{a}_{\mathrm{w}}$ (Medina et al., 2014; Medina et al., 2015). Further, Bernáldez et al. (2017) studied the effect of interactions of temperature and $\mathrm{a}_{\mathrm{w}}$ on the biosynthetic regulatory gene (aflR) expression and production of AFB1 by A. flavus in maize. They observed the optimum growth of $A$. flavus at $30^{\circ} \mathrm{C} / 0.99 \mathrm{a}_{\mathrm{w}}$ with no growth at $20^{\circ} \mathrm{C} / 0.90 \mathrm{a}_{\mathrm{w}}$. Both temperature and $\mathrm{a}_{\mathrm{w}}$ influenced the relative aflR gene expression and AFB1 production, however, the trends for the production of AFB1 were not in accordance with the gene expression. Further, the effect of temperature (20, 27 , and $\left.35^{\circ} \mathrm{C}\right)$ and $\mathrm{a}_{\mathrm{w}}(0.82,0.86,0.90,0.94$, and 0.98$)$ on the growth of A. flavus and A. parasiticus along with the production of AFB1 were investigated on ground Nyjer seeds by Gizachew et al. (2019). The maximum AFB1 production was observed at $27^{\circ} \mathrm{C} / 0.90 \mathrm{a}_{\mathrm{w}}$ for both $A$. flavus and A. parasiticus. In addition to this, the fungi showed optimum growth on polished rice in the range of $28-37^{\circ} \mathrm{C} / 0.92-0.96 \mathrm{a}_{\mathrm{w}}$. The maximum AFB1 was produced at $33^{\circ} \mathrm{C} / 0.96 \mathrm{a}_{\mathrm{W}}$ (Lv et al., 2019). Based on the investigation by Battilani et al. (2016) on the possible emergence of AFB1 in cereals in the European Union as a result of climate change, for every $2^{\circ} \mathrm{C}$ increase in temperature, there is an increase in AFs risk in the various regions of Spain, Italy, Greece, Portugal, Bulgaria, Albania, Cyprus and Turkey. The risk for AFs contamination in maize is likely to increase in Europe due to favorable climatic conditions for A. flavus in the next 30 years (Moretti et al., 2019). Therefore, proper detection methods and control strategies are crucial to combat the burning issues of AFs in food and feed.

\section{DETECTION METHODS}

The detection of AFs has been performed by the Association of Official Analytical Chemists (AOAC) official method in food and feed samples (Kumar et al., 2017). Among the most commonly employed methods are chromatographic methods like thin layer chromatography (TLC) (Fallah et al., 2011), high performance liquid chromatography (HPLC) and liquid chromatography mass spectroscopy (LCMS) (McDanell et al., 1988; Samarajeewa et al., 1991; Herzallah, 2009), besides the enzyme-linked immunosorbent assay (ELISA) (Tabari et al., 2011; Andrade et al., 2013; Sulyok et al., 2015). However, the drawbacks of these standard methods are that they are unsuitable for rapid and real-time applications in food and feed samples as they are tedious, time-consuming and require skilled personnel to operate. Therefore, rapid and robust methods like polymerase chain reaction (PCR) and non-destructive methods based on fluorescence/near-infrared spectroscopy (FS/NIRS) and hyperspectral imaging (HSI) have emerged for the quick and easy detection of AFs (Tao et al., 2018).

Hussain et al. (2015) utilized the PCR technique for the molecular detection of AF producing A. flavus from peanuts. Similarly, the avfA, omtA, and ver-1 genes encoding the major enzymes in AF-biosynthesis were used as target genes for detecting AFs using multiplex PCR (Yang et al., 2004). Further, PCR was employed to detect AF-producing genes in Aspergillus species in Iranian pistachio nuts for their aflatoxigenic effect (Rahimi et al., 2008). In addition, Kim et al. (2014) utilized PCR, ELISA and HPLC for the detection of AFs from A. oryzae isolated from different Korean foods. HSI uses the integration of both imaging and spectroscopy to record spatial and spectral characteristics of a given sample (Wu and Sun, 2013; Ropodi et al., 2016; Shrestha et al., 2016; Siche et al., 2016). The visible/near-infrared (VNIR) HSI has been utilized for the identification of maize kernels of different varieties (Zhang et al., 2012; Wang et al., 2016). VNIR or short-wave (SWNIR) HSI techniques are feasible for the detection of AFs as well as identification of different fungal species in maize (Pearson and Wicklow, 2006; Williams et al., 2012; Wang et al., 2015a,b). Later, Kimuli et al. (2018b) used the VNIR-HSI system to detect AFB1 on surfaces of maize kernels from Georgia, Illinois, Indiana and Nebraska of United States. Chu et al. (2017) used short-wave infrared (SWIR) HIS to detect AFB1 in single maize kernels. But as the image quality could not effectively classify AFB1 level qualitatively in individual maize kernels, therefore, to improve this Kimuli et al. (2018a) further combined the SWIR-HSI system with chemometric data analysis for the better detection of AFB1 on the surfaces of maize kernels. Furthermore, the color-encoded lateral flow immunoassay (LFIA) technique has been used for the simultaneous detection of AFB1 as well as fumonisins in a single test line (Di Nardo et al., 2019).

To further enhance the sensitivity and detection of AFs in food and feed, nanoparticles (NPs) based on $\mathrm{Au} / \mathrm{Ag}$, carbon (CBNs), magnetic (MNPs), Quantum dots (QDs), up-conversion (UCNPs), metal-organic frameworks (MOFs) as well as hybrid nanostructures have been utilized (Xue et al., 2019). Rui et al. (2019) prepared molecular imprinted polymers (FDU12@MIPs) using structural analog of AFs. This highly selective surface was used as an extraction sorbent in conjunction with HPLC for the detection of AFs in different food and feed samples. In addition to this, the use of biosensors compared to other spectrophotometric or chromatographic methods allow for higher selectivity, direct detection with minimal sample pretreatment, minimal cost, portability and on-field analysis of mycotoxins (Rotariu et al., 2016). Selvolini et al. (2019) utilized 
an electrochemical enzyme-linked oligonucleotide array for easy and quick multi-detection of AFB1 in maize. Furthermore, assays based on aptamer have been developed for the rapid detection of AFB1. Wang et al. (2019) successfully detected the AFB1 spiked in wine, methanol and corn flour samples using the simple aptamer molecular beacon assay, which has the potential for the rapid detection of AFs in the food and feed.

\section{MASKED MYCOTOXINS AS A MAJOR CONCERN IN DETECTION}

Masked mycotoxins pose a major concern in food and feed as they are not identified and detected by the usually employed detection techniques (Kamle et al., 2019). These are the mycotoxins produced by fungi but are modified by plant enzymes during the infection stages. They are present in vacuoles in the soluble form or bound to macromolecules, therefore, are unable to be identified by routine analysis processes and referred to as masked mycotoxins (Berthiller et al., 2013). However, the modified AFs can hydrolyze back into the toxic forms during food processing and/or digestion process (Gareis et al., 1990; Nagl et al., 2014; Broekaert et al., 2015). Some of these modified toxins are present in different forms as complexes with matrix compounds, hence also referred to as matrix-associated mycotoxins (Rychlik et al., 2014). The masked mycotoxins have been reported to occur in Asia, Africa, America and Europe. Therefore, a high amount of masked mycotoxins prevailing in various food and feed can pose serious health issues to both humans and animals (Zhang et al., 2019). Therefore, the detection of masked mycotoxins is an essential part to ensure food and feed safety. Masked fumonisins were determined through hydrolysis where modified forms were converted back to their free forms and subsequently analyzed and detected through LC/MS/MS (Dall'Asta et al., 2008; Dall'Asta et al., 2009). The hydrolytic process may involve either alkaline, acidic or enzymatic treatments (Dall'Asta et al., 2009; Beloglazova et al., 2013; Vidal et al., 2018). However, there is less information available on the masked AFs as most of the preference is given for the detection of free AFs in agricultural food and feed. Therefore, methods like in vitro digestion and hydrolysis, as applied in case of masked fumonisins, can be carried out for masked AFs in food and feed followed by detection with LC/MS/MS and confirmation by other methods like ELISA to ensure the food and feed safety.

\section{CONTROL STRATEGIES OF AFLATOXINS}

Implementation of advanced agricultural technologies, good agricultural practices (GAPs), good manufacturing practices (GMPs) and good storage practices (GSPs) can mitigate the mycotoxins contamination (Kamle et al., 2019). The novel processing techniques involving a microwave, UV, pulsed light, electrolyzed water, cold plasma, ozone, electron beam and gamma $(\gamma)$ irradiation treatment have the potential for AFs management and preserving and maintaining the quality of agricultural and food products (Jalili et al., 2010; Pankaj et al., 2018). The application of ozone degrades AFs by an electrophilic attack on the double-bonded carbons (C8-C9) of the furan ring resulting in the formation of primary ozonides followed by rearrangement into monozonide derivatives like aldehydes, ketones and organic acids (Jalili, 2016). Further, the detailed mechanism of ozone degrading AFB1 has been discussed by Diao et al. (2013). The application of ozone for the degradation AF is limited in food products due to the cost factor (Womack et al., 2014). Similarly, the mechanism behind the AF degradation by gamma rays lies on the effects of free radicals produced during the radiolysis of water and other components that attacks the terminal furan ring of AFB1 resulting in byproducts of reduced biological activity (Rustom, 1997). The degradation efficiency of gamma irradiation is more effective when combined with other technologies.

In addition to these, several synthetic and natural food additives have been studied for AFs reduction in food and feed. For examples, the use of citric acid in combination with moisture under high temperature $\left(200^{\circ} \mathrm{C}\right)$ and pressure $(8 \mathrm{~N})$ was effective in degrading AFs in extruded sorghum (MéndezAlbores et al., 2009). On the other hand, the efficacy of sodium hydrosulphite $\left(\mathrm{Na}_{2} \mathrm{~S}_{2} \mathrm{O}_{4}\right)$ was enhanced with increased pressure for AFs reduction in black pepper (Jalili and Jinap, 2012). Furthermore, as a part of biological control measures, Anjaiah et al. (2006) reported that inoculation of antagonistic strains of Pseudomonas, Bacillus and Trichoderma spp. had a significant reduction of $A$. flavus in pre-harvest crops. The non-aflatoxin forming strains of A. flavus and other nontoxigenic molds are prominent biological control agents against AFs contamination (Dorner et al., 2003; Udomkun et al., 2017). The application of each technique has its advantages and disadvantages. Therefore, biocontrol measures in synchrony with other physical and chemical methods along with improved packaging materials should be implemented to attain food safety and security.

\section{CONCLUSION}

Aflatoxins' contamination of crops at pre- and postharvest conditions can be controlled to some extent by the implementation of good agricultural practices (GAPs), good manufacturing practices (GMPs) and good storage practices (GSPs). Further, the novel processing technologies involving a microwave, UV, pulsed light, electrolyzed water, cold plasma, ozone, electron beam or gamma $(\gamma)$ irradiation in combination with either biological, physical, chemical or genetic engineering methods have the potential to improve the efficiency of AFs decontamination as well as to overcome the limitations of any specific technology. However, it is vital to understand the mechanisms of AFs detoxification so that no AF-residues are left behind when these methods are applied in food and feed samples. Furthermore, as there is less information on the masked AFs present in food and feed, it requires in-depth research and understanding with regards to adequate hydrolysis, identification, detection and control strategies. Therefore, 
utilization of the novel technologies along with raising public awareness for implementing GAPs, GMPs and GSPs are crucial for controlling AFs contamination in food and feed to ensure food safety and security and to safeguard human and animal health.

\section{AUTHOR CONTRIBUTIONS}

PK conceived and designed the manuscript. DM, PK, and MK wrote the manuscript. KL, KD, and SD helped in the editing of the manuscript. PK and SK critically reviewed the manuscript and did the required editing.

\section{REFERENCES}

Abd-Elghany, S. M., and Sallam, K. I. (2015). Rapid determination of total aflatoxins and ochratoxins $\mathrm{A}$ in meat products by immuno-affinity fluorimetry. Food Chem. 179, 253-256. doi: 10.1016/j.foodchem.2015.01.140

Achaglinkame, M. A., Opoku, N., and Amagloh, F. K. (2017). Aflatoxin contamination in cereals and legumes to reconsider usage as complementary food ingredients for Ghanaian infants: a review. J. Nutr. Intermed. Metab. 10, 1-7. doi: 10.1016/j.jnim.2017.09.001

Andrade, P. D., and Caldas, E. D. (2015). Aflatoxins in cereals: worldwide occurrence and dietary risk assessment. World Mycotoxin J. 8, 415-431. doi: 10.3920/wmj2014.1847

Andrade, P. D., da Silva, J. L. G., and Caldas, E. D. (2013). Simultaneous analysis of aflatoxins B1, B2, G1, G2, M1 and ochratoxin A in breast milk by highperformance liquid chromatography/fluorescence after liquid-liquid extraction with low temperature purification (LLE-LTP). J. Chromatogr. A 1304, 61-68. doi: 10.1016/j.chroma.2013.06.049

Anjaiah, V., Thakur, R. P., and Koedam, N. (2006). Evaluation of bacteria and Trichoderma for biocontrol of pre-harvest seed infection by Aspergillus flavus in groundnut. Biocontrol. Sci. Technol. 16, 431-436. doi: 10.1080/ 09583150500532337

Aycicek, H., Aksoy, A., and Saygi, S. (2005). Determination of aflatoxin levels in some dairy and food products which consumed in Ankara. Turkey. Food Control 16, 263-266. doi: 10.1016/j.foodcont.2004.03.004

Aydin, A., Erkan, M. E., Başkaya, R., and Ciftcioglu, G. (2007). Determination of aflatoxin B1 levels in powdered red pepper. Food Control 18, 1015-1018. doi: 10.1007/s10661-015-4402-0

Azziz-Baumgartner, E., Lindblade, K., Gieseker, K., Rogers, H. S., Kieszak, S., Njapau, H., et al. (2005). Case-control study of an acute aflatoxicosis outbreak, Kenya, 2004. Environ. Health Perspect. 113, 1779-1783. doi: 10.1289/ehp. 8384

Bahrami, R., Shahbazi, Y., and Nikousefat, Z. (2016). Aflatoxin M1 in milk and traditional dairy products from west part of Iran: occurrence and seasonal variation with an emphasis on risk assessment of human exposure. Food Control 62, 250-256. doi: 10.1016/j.foodcont.2015.10.039

Baltaci, C., İlyasoğlu, H., and Cavrar, S. (2012). Aflatoxin levels in raw and processed hazelnuts in Turkey. Food Addit. Contam. Part B 5, 83-86. doi: 10.1080/19393210.2012.656146

Battilani, P., Formenti, S., Ramponi, C., and Rossi, V. (2011). Dynamic of water activity in maize hybrids is crucial for fumonisin contamination in kernels. J. Cereal Sci. 54, 467-472. doi: 10.1016/j.jcs.2011.08.014

Battilani, P., Toscano, P., Van der Fels-Klerx, H., Moretti, A., Leggieri, M. C., Brera, C., et al. (2016). Aflatoxin B 1 contamination in maize in Europe increases due to climate change. Sci. Rep. 6:24328. doi: 10.1038/srep 24328

Baydan, E., Küçükersan, S., Yurdakök, D. B., Aydin, F. G., Sevin, S., Arslanbaş, E., et al. (2016). Comparison of nutritional composition (moisture, ash, crude protein, nitrogen) and safety (aflatoxin, nitrate/nitrite) of organic and conventional rice and lentil samples consumed in Ankara. Ankara Univ. Vet. Fak. Derg. 63, 365-370. doi: 10.1501/vetfak_0000002754

\section{FUNDING}

This work was supported by the 2014 Yeungnam University Research Grant (214A345038).

\section{ACKNOWLEDGMENTS}

All authors are highly grateful to the authority of the respective department and Institution for their support in doing this research. PK would like to thank the DSTSERB (file no. ECR/2017/001143) and DBT-Twinning (No. BT/PR24741/NER/95/659/2017) for their financial support.

Beloglazova, N. V., De Boevre, M., Goryacheva, I. Y., Werbrouck, S., Guo, Y., and De Saeger, S. (2013). Immunochemical approach for zearalenone-4-glucoside determination. Talanta 106, 422-430. doi: 10.1016/j.talanta.2013.01.020

Bernáldez, V., Córdoba, J. J., Magan, N., Peromingo, B., and Rodríguez, A. (2017). The influence of ecophysiological factors on growth, aflR gene expression and aflatoxin B1 production by a type strain of Aspergillus flavus. LWT Food Sci. Technol. 83, 283-291. doi: 10.1016/j.lwt.2017.05.030

Berthiller, F., Crews, C., Dall'Asta, C., Saeger, S. D., Haesaert, G., Karlovsky, P., et al. (2013). Masked mycotoxins: a review. Mol. Nutr. Food Res. 57, 165-186. doi: 10.1002/mnfr.201100764

Binder, E. M., Tan, L. M., Chin, L. J., Handl, J., and Richard, J. (2007). Worldwide occurrence of mycotoxins in commodities, feeds and feed ingredients. Anim. Feed Sci. Technol. 137, 265-282. doi: 10.1080/19393210.2011.589034

Broekaert, N., Devreese, M., De Mil, T., Fraeyman, S., Antonissen, G., De Baere, S., et al. (2015). Oral bioavailability, hydrolysis, and comparative toxicokinetics of 3-acetyldeoxynivalenol and 15-acetyldeoxynivalenol in broiler chickens and pigs. J. Agric. Food Chem. 63, 8734-8742. doi: 10.1021/acs.jafc.5b03270

Bumbangi, N. F., Muma, J. B., Choongo, K., Mukanga, M., Velu, M., Veldman, F., et al. (2016). Occurrence and factors associated with aflatoxin contamination of raw peanuts from Lusaka district's markets. Zambia. Food Control 68, 291-296. doi: 10.1016/j.foodcont.2016.04.004

Chala, A., Mohammed, A., Ayalew, A., and Skinnes, H. (2013). Natural occurrence of aflatoxins in groundnut (Arachis hypogaea L.) from eastern Ethiopia. Food Control 30, 602-605. doi: 10.1016/j.foodcont.2012.08.023

Chen, Y.-C., Liao, C.-D., Lin, H.-Y., Chiueh, L.-C., and Shih, D. Y.-C. (2013). Survey of aflatoxin contamination in peanut products in Taiwan from 1997 to 2011. J. Food Drug Anal. 21, 247-252. doi: 10.1016/j.jfda.2013.07.001

Chu, X., Wang, W., Yoon, S.-C., Ni, X., and Heitschmidt, G. W. (2017). Detection of aflatoxin B1 (AFB1) in individual maize kernels using short wave infrared (SWIR) hyperspectral imaging. Biosyst. Eng. 157, 13-23. doi: 10.1016/j. biosystemseng.2017.02.005

Cotty, P. J., and Jaime-Garcia, R. (2007). Influences of climate on aflatoxin producing fungi and aflatoxin contamination. Int. J. Food Microbiol. 119, 109-115. doi: 10.1016/j.ijfoodmicro.2007.07.060

Dall'Asta, C., Galaverna, G., Aureli, G., Dossena, A., and Marchelli, R. (2008). A LC/MS/MS method for the simultaneous quantification of free and masked fumonisins in maize and maize-based products. World Mycotoxin J. 1, 237-246. doi: 10.3920/wmj2008.x040

Dall'Asta, C., Mangia, M., Berthiller, F., Molinelli, A., Sulyok, M., Schuhmacher, R., et al. (2009). Difficulties in fumonisin determination: the issue of hidden fumonisins. Anal. Bioanal. Chem. 395, 1335-1345. doi: 10.1007/s00216-0092933-3

De Roma, A., Rossini, C., Ritieni, A., Gallo, P., and Esposito, M. (2017). A survey on the Aflatoxin M1 occurrence and seasonal variation in buffalo and cow milk from Southern Italy. Food Control 81, 30-33. doi: 10.1016/j.foodcont.2017. 05.034

Di Nardo, F., Alladio, E., Baggiani, C., Cavalera, S., Giovannoli, C., Spano, G., et al. (2019). Colour-encoded lateral flow immunoassay for the simultaneous detection of aflatoxin B1 and type-B fumonisins in a single Test line. Talanta 192, 288-294. doi: 10.1016/j.talanta.2018.09.037 
Diao, E., Hou, H., and Dong, H. (2013). Ozonolysis mechanism and influencing factors of aflatoxin B1: a review. Trends Food Sci. Technol. 33, 21-26. doi: 10.1016/j.tifs.2013.06.002

Dorner, J. W., Cole, R. J., Connick, W. J., Daigle, D. J., McGuire, M. R., and Shasha, B. S. (2003). Evaluation of biological control formulations to reduce aflatoxin contamination in peanuts. Biol. Control 26, 318-324. doi: 10.1016/ s1049-9644(02)00139-1

Duarte, S. C., Almeida, A. M., Teixeira, A. S., Pereira, A. L., Falcão, A. C., Pena, A., et al. (2013). Aflatoxin M1 in marketed milk in Portugal: assessment of human and animal exposure. Food Control 30, 411-417. doi: 10.1016/j.foodcont.2012. 08.002

EC (2007). European Commission. Commission Regulation (EC) No 1126/2007. of 28 September 2007 amending regulation (EC) no 1881/2006 setting maximum levels for certain contaminants in foodstuffs as regards Fusarium toxins in maize and maize products. Off. J. Eur. Union L 255, 14-17.

EC (2010). European Commission. Commission Regulation (EC) No 165/2010 of 26 February 2010 amending Regulation (EC) No 1881/2006 setting maximum levels for certain contaminants in foodstuffs as regards aflatoxins. Off. J. Eur. Union L 50, 8-12.

Elshafie, A. E., Al-Rashdi, T. A., Al-Bahry, S. N., and Bakheit, C. S. (2002). Fungi and aflatoxins associated with spices in the Sultanate of Oman. Mycopathologia $155,155-160$.

Fallah, A. A., Rahnama, M., Jafari, T., and Saei-Dehkordi, S. S. (2011). Seasonal variation of aflatoxin M1 contamination in industrial and traditional Iranian dairy products. Food Control 22, 1653-1656. doi: 10.1016/j.foodcont.2011. 03.024

FAO (1996). Rome Declaration on World Food Security and World Food Summit Plan of Action: World Food Summit 13-17 November 1996. Rome: FAO.

Filazi, A., and Sireli, U. T. (2013). "Occurrence of aflatoxins in food," in AflatoxinsRecent Advances and Future Prospects, ed. M. Razzaghi-Abyaneh, (Ankara: BoD-Books on Demand).

Fung, F., and Clark, R. F. (2004). Health effects of mycotoxins: a toxicological overview. J. Toxicol. Clin. Toxicol. 42, 217-234. doi: 10.1081/clt-120030947

Gareis, M., Bauer, J., Thiem, J., Plank, G., Grabley, S., and Gedek, B. (1990). Cleavage of zearalenone-glycoside, a "masked" mycotoxin, during digestion in swine. J. Vet. Med. B 37, 236-240. doi: 10.1111/j.1439-0450.1990.tb01052.x

Ghali, R., Khlifa, K. H., Ghorbel, H., Maaroufi, K., and Hedilli, A. (2010). Aflatoxin determination in commonly consumed foods in Tunisia. J. Sci. Food Agric. 90, 2347-2351. doi: 10.1002/jsfa.4069

Gizachew, D., Chang, C.-H., Szonyi, B., De, La Torre, and Ting, W.-T. E. (2019). Aflatoxin B1 (AFB1) production by Aspergillus flavus and Aspergillus parasiticus on ground Nyjer seeds: the effect of water activity and temperature. Int. J. Food Microbiol. 296, 8-13. doi: 10.1016/j.ijfoodmicro.2019.02.017

Granados-Chinchilla, F., Molina, A., Chavarría, G., Alfaro-Cascante, M., BogantesLedezma, D., and Murillo-Williams, A. (2017). Aflatoxins occurrence through the food chain in Costa Rica: applying the One Health approach to mycotoxin surveillance. Food control 82, 217-226. doi: 10.1016/j.foodcont.2017.06.023

Guengerich, F. P., Johnson, W. W., Shimada, T., Ueng, Y.-F., Yamazaki, H., and Langouët, S. (1998). Activation and detoxication of aflatoxin B1. Mutat. Res. 402, 121-128. doi: 10.1016/s0027-5107(97)00289-3

Guo, Y., Yuan, Y., and Yue, T. (2013). Aflatoxin M1 in milk products in China and dietary risk assessment. J. Food Prot. 76, 849-853. doi: 10.4315/0362-028X.JFP12-419

Gürses, M. (2006). Mycoflora and aflatoxin content of hazelnuts, walnuts, peanuts, almonds and roasted chickpeas (LEBLEBI) sold in Turkey. Int. J. Food Prop. 9, 395-399. doi: 10.1080/10942910600596597

Herzallah, S. M. (2009). Determination of aflatoxins in eggs, milk, meat and meat products using HPLC fluorescent and UV detectors. Food Chem. 114, 1141-1146. doi: 10.1016/j.foodchem.2008.10.077

Hesseltine, C. W. (1974). Natural occurrence of mycotoxins in cereals. Mycopathol. Mycol. Appl. 53, 141-153. doi: 10.1007/bf02127204

Hussain, A., Afzal, A., Irfan, M., and Malik, K. A. (2015). Molecular detection of aflatoxin producing strains of Aspergillus flavus from peanut (Arachis hypogaea). Turk. J. Agric. Food Sci. Technol. 3, 335-341.

IARC (2012). International Agency for Research on Cancer. Review of Human Carcinogens: Chemical Agents and Related Occupations. Geneva: World health organization.
Iqbal, S. Z., Asi, M. R., Hanif, U., Zuber, M., and Jinap, S. (2016). The presence of aflatoxins and ochratoxin $\mathrm{A}$ in rice and rice products; and evaluation of dietary intake. Food Chem. 210, 135-140. doi: 10.1016/j.foodchem.2016.04.104

Iqbal, S. Z., Jinap, S., Pirouz, A. A., and Faizal, A. R. A. (2015). Aflatoxin M1 in milk and dairy products, occurrence and recent challenges: a review. Trends Food Sci. Technol. 46, 110-119. doi: 10.1016/j.tifs.2015.08.005

Jalili, M. (2016). A review on aflatoxins reduction in food. Iran. J. Health Saf. Environ. 3, 445-459.

Jalili, M., and Jinap, S. (2012). Role of sodium hydrosulphite and pressure on the reduction of aflatoxins and ochratoxin A in black pepper. Food Control 27, 11-15. doi: 10.1080/19440049.2010.551300

Jalili, M., Jinap, S., and Noranizan, A. (2010). Effect of gamma radiation on reduction of mycotoxins in black pepper. Food Control 21, 1388-1393. doi: 10.1016/j.foodcont.2010.04.012

Juan, C., Ritieni, A., and Mañes, J. (2012). Determination of trichothecenes and zearalenones in grain cereal, flour and bread by liquid chromatography tandem mass spectrometry. Food Chem. 134, 2389-2397. doi: 10.1016/j.foodchem.2012. 04.051

Kabak, B. (2016). Aflatoxins in hazelnuts and dried figs: occurrence and exposure assessment. Food Chem. 211, 8-16. doi: 10.1016/j.foodchem.2016.04.141

Kamle, M., Mahato, D. K., Devi, S., Lee, K. E., Kang, S. G., and Kumar, P. (2019). Fumonisins: impact on agriculture. food, and human health and their management strategies. Toxins 11:328. doi: 10.3390/toxins 11060328

Kara, G. N., Ozbey, F., and Kabak, B. (2015). Co-occurrence of aflatoxins and ochratoxin A in cereal flours commercialised in Turkey. Food Control 54, 275-281. doi: 10.1016/j.foodcont.2015.02.014

Kim, N. Y., Lee, J. H., Lee, I., and Ji, G. E. (2014). An evaluation of aflatoxin and cyclopiazonic acid production in Aspergillus oryzae. J. Food Prot. 77, 1010-1016. doi: 10.4315/0362-028X.JFP-13-448

Kimuli, D., Wang, W., Jiang, H., Zhao, X., and Chu, X. (2018a). Application of SWIR hyperspectral imaging and chemometrics for identification of aflatoxin B1 contaminated maize kernels. Infrared Phys. Technol. 89, 351-362. doi: 10.1016/j.infrared.2018.01.026

Kimuli, D., Wang, W., Lawrence, K. C., Yoon, S.-C., Ni, X., and Heitschmidt, G. W. (2018b). Utilisation of visible/near-infrared hyperspectral images to classify aflatoxin B1 contaminated maize kernels. Biosyst. Eng. 166, 150-160. doi: 10.1016/j.biosystemseng.2017.11.018

Kos, J., Mastilović, J., Hajnal, E. J., and Šarić, B. (2013). Natural occurrence of aflatoxins in maize harvested in Serbia during 2009-2012. Food Control 34, 31-34. doi: 10.1016/j.foodcont.2013.04.004

Kumagai, S., Nakajima, M., Tabata, S., Ishikuro, E., Tanaka, T., Norizuki, H., et al. (2008). Aflatoxin and ochratoxin A contamination of retail foods and intake of these mycotoxins in Japan. Food Addit. Contam. 25, 1101-1106. doi: 10.1080/ 02652030802226187

Kumar, P., Mahato, D. K., Kamle, M., Mohanta, T. K., and Kang, S. G. (2017). Aflatoxins: a global concern for food safety, human health and their management. Front. Microbiol. 7:2170. doi: 10.3389/fmicb.2016.02170

Lai, X., Liu, R., Ruan, C., Zhang, H., and Liu, C. (2015). Occurrence of aflatoxins and ochratoxin $\mathrm{A}$ in rice samples from six provinces in China. Food Control 50, 401-404. doi: 10.1016/j.foodcont.2014.09.029

Lee, H. S., Nguyen-Viet, H., Lindahl, J., Thanh, H. M., Khanh, T. N., Hien, L. T. T., et al. (2017). A survey of aflatoxin B1 in maize and awareness of aflatoxins in Vietnam. World Mycotoxin J. 10, 195-202. doi: 10.3920/wmj2016.2144

Lewis, L., Onsongo, M., Njapau, H., Schurz-Rogers, H., Luber, G., Kieszak, S., et al. (2005). Aflatoxin contamination of commercial maize products during an outbreak of acute aflatoxicosis in eastern and central Kenya. Environ. Health Perspect. 113, 1763-1767. doi: 10.1289/ehp.7998

Lippolis, V., Irurhe, O., Porricelli, A. C. R., Cortese, M., Schena, R., Imafidon, T., et al. (2017). Natural co-occurrence of aflatoxins and ochratoxin A in ginger (Zingiber officinale) from Nigeria. Food control 73, 1061-1067. doi: 10.1016/j. foodcont.2016.10.026

Lombard, M. J. (2014). Mycotoxin exposure and infant and young child growth in Africa: what do we know? Ann. Nutr. Metabol. 64(Suppl. 2), 42-52. doi: $10.1159 / 000365126$

Lutfullah, G., and Hussain, A. (2012). Studies on contamination level of aflatoxins in some cereals and beans of Pakistan. Food Control 23, 32-36. doi: 10.1016/j. foodcont.2011.06.004 
Lv, C., Jin, J., Wang, P., Dai, X., Liu, Y., Zheng, M., et al. (2019). Interaction of water activity and temperature on the growth, gene expression and aflatoxin production by Aspergillus flavus on paddy and polished rice. Food Chem. 293, 472-478. doi: 10.1016/j.foodchem.2019.05.009

Magan, N. (2007). Fungi in extreme environments. Mycota 4, 85-103. doi: 10.1007/ 978-3-540-71840-6_6

Magan, N., and Aldred, D. (2007). Post-harvest control strategies: minimizing mycotoxins in the food chain. Int. J. Food Microbiol. 119, 131-139. doi: 10. 1016/j.ijfoodmicro.2007.07.034

Marasas, W. F. O., Gelderblom, W. C. A., Shephard, G. S., and Vismer, H. F. (2008). Mycotoxins: a global problem. Mycotoxins: Detection Methods, Management, Public Health and Agricultural Trade, 4th Edn. Oxford: CABI, 29-39.

Martinez-Miranda, M. M., Rosero-Moreano, M., and Taborda-Ocampo, G. (2019). Occurrence, dietary exposure and risk assessment of aflatoxins in arepa, bread and rice. Food Control 98, 359-366. doi: 10.1016/j.foodcont.2018.11.046

Masood, M., Iqbal, S. Z., Asi, M. R., and Malik, N. (2015). Natural occurrence of aflatoxins in dry fruits and edible nuts. Food Control 55, 62-65. doi: 10.1016/j. foodcont.2015.02.041

Matumba, L., Monjerezi, M., Biswick, T., Mwatseteza, J., Makumba, W., Kamangira, D., et al. (2014). A survey of the incidence and level of aflatoxin contamination in a range of locally and imported processed foods on Malawian retail market. Food control 39, 87-91. doi: 10.1016/j.foodcont.2013.09.068

McDanell, R., McLean, A. E. M., Hanley, A. B., Heaney, R. K., and Fenwick, G. R. (1988). Chemical and biological properties of indole glucosinolates (glucobrassicins): a review. Food Chem. Toxicol. 26, 59-70. doi: 10.1016/02786915(88)90042-7

Medina, A., Akbar, A., Baazeem, A., Rodriguez, A., and Magan, N. (2017a). Climate change, food security and mycotoxins: do we know enough? Fungal Biol. Rev. 31, 143-154. doi: 10.1016/j.fbr.2017.04.002

Medina, A., Gilbert, M. K., Mack, B. M., OBrian, G. R., Rodriguez, A., Bhatnagar, D., et al. (2017b). Interactions between water activity and temperature on the Aspergillus flavus transcriptome and aflatoxin B1 production. Int. J. Food Microbiol. 256, 36-44. doi: 10.1016/j.ijfoodmicro.2017.05.020

Medina, A., Rodríguez, A., Sultan, Y., and Magan, N. (2014). Climate change factors and Aspergillus flavus: effects on gene expression, growth and aflatoxin production. World Mycotoxin J. 8, 171-179. doi: 10.3920/wmj2014.1726

Medina, A., Schmidt-Heydt, M., Rodriguez, A., Parra, R., Geisen, R., and Magan, N. (2015). Impacts of environmental stress on growth, secondary metabolite biosynthetic gene clusters and metabolite production of xerotolerant/xerophilic fungi. Curr. Genet. 61, 325-334. doi: 10.1007/s00294-014-0455-9

Méndez-Albores, A., Veles-Medina, J., Urbina-Álvarez, E., Martínez-Bustos, F., and Moreno-Martínez, E. (2009). Effect of citric acid on aflatoxin degradation and on functional and textural properties of extruded sorghum. Anim. Feed Sci. Technol. 150, 316-329. doi: 10.1016/j.anifeedsci.2008.10.007

Milhome, M. A. L., Lima, C. G., De Lima, L. K., Lima, F. A. F., Sousa, D. O. B., and Nascimento, R. F. (2014). Occurrence of aflatoxins in cashew nuts produced in northeastern Brazil. Food control 42, 34-37. doi: 10.1016/j.foodcont.2014. 01.033

Moretti, A., Pascale, M., and Logrieco, A. F. (2019). Mycotoxin risks under a climate change scenario in Europe. Trends Food Sci. Technol. 84, 38-40. doi: 10.1016/j.tifs.2018.03.008

Mudili, V., Siddaih, C. N., Nagesh, M., Garapati, P., Naveen Kumar, K., Murali, H. S., et al. (2014). Mould incidence and mycotoxin contamination in freshly harvested maize kernels originated from India. J. Sci. Food Agric. 94, 2674-2683. doi: $10.1002 /$ jsfa. 6608

Murashiki, T. C., Chidewe, C., Benhura, M. A., Maringe, D. T., Dembedza, M. P., Manema, L. R., et al. (2017). Levels and daily intake estimates of aflatoxin B1 and fumonisin B1 in maize consumed by rural households in Shamva and Makoni districts of Zimbabwe. Food Control 72, 105-109. doi: 10.1016/j.foodcont.2016. 07.040

Mutegi, C. K., Ngugi, H. K., Hendriks, S. L., and Jones, R. B. (2009). Prevalence and factors associated with aflatoxin contamination of peanuts from Western Kenya. Int. J. Food Microbiol. 130, 27-34. doi: 10.1016/j.ijfoodmicro.2008. 12.030

Nagl, V., Woechtl, B., Schwartz-Zimmermann, H. E., Hennig-Pauka, I., Moll, W.-D., Adam, G., et al. (2014). Metabolism of the masked mycotoxin deoxynivalenol-3-glucoside in pigs. Toxicol. Lett. 229, 190-197. doi: 10.1016/ j.toxlet.2014.06.032
Neamatallah, A., and Serdar, S. A. (2013). Incidence of aflatoxins in commercial nuts in the holy city of Mekkah. Food control 29, 121-124. doi: 10.1016/j. foodcont.2012.06.004

Nesci, A., Etcheverry, M., and Magan, N. (2004). Osmotic and matric potential effects on growth, sugar alcohol and sugar accumulation by Aspergillus section Flavi strains from Argentina. J. Appl. Microbiol. 96, 965-972. doi: 10.1111/j. 1365-2672.2004.02246.x

Nordkvist, E., Stepinska, A., and Häggblom, P. (2009). Aflatoxin contamination of consumer milk caused by contaminated rice by-products in compound cattle feed. J. Sci. Food Agric. 89, 359-361. doi: 10.1002/jsfa.3445

Pankaj, S. K., Shi, H., and Keener, K. M. (2018). A review of novel physical and chemical decontamination technologies for aflatoxin in food. Trends Food Sci. Technol. 71, 73-83. doi: 10.1016/j.tifs.2017.11.007

Payne, G. A., and Brown, M. P. (1998). Genetics and physiology of aflatoxin biosynthesis. Annu. Rev. Phytopathol. 36, 329-362. doi: 10.1146/annurev. phyto.36.1.329

Pearson, T. C., and Wicklow, D. T. (2006). Detection of corn kernels infected by fungi. Trans. ASABE 49, 1235-1245. doi: 10.13031/2013.21723

Perrone, G., Haidukowski, M., Stea, G., Epifani, F., Bandyopadhyay, R., Leslie, J. F., et al. (2014). Population structure and Aflatoxin production by Aspergillus Sect. Flavi from maize in Nigeria and Ghana. Food Microbiol. 41, 52-59. doi: 10.1016/j.fm.2013.12.005

Picinin, L. C. A., Cerqueira, M. M. O. P., Vargas, E. A., Lana, ÂM. Q., Toaldo, I. M., and Bordignon-Luiz, M. T. (2013). Influence of climate conditions on aflatoxin M1 contamination in raw milk from Minas Gerais State, Brazil. Food Control 31, 419-424. doi: 10.1016/j.foodcont.2012.10.024

Prelle, A., Spadaro, D., Garibaldi, A., and Gullino, M. L. (2014). Co-occurrence of aflatoxins and ochratoxin A in spices commercialized in Italy. Food Control 39, 192-197. doi: 10.1016/j.foodcont.2013.11.013

Prietto, L., Moraes, P. S., Kraus, R. B., Meneghetti, V., Fagundes, C. A. A., and Furlong, E. B. (2015). Post-harvest operations and aflatoxin levels in rice (Oryza sativa). Crop Protection 78, 172-177. doi: 10.1016/j.cropro.2015.09.011

Probst, C., Njapau, H., and Cotty, P. J. (2007). Outbreak of an acute aflatoxicosis in Kenya in 2004: identification of the causal agent. Appl. Environ. Microbiol. 73, 2762-2764. doi: 10.1128/aem.02370-06

Rahimi, P., Sharifnabi, B., and Bahar, M. (2008). Detection of aflatoxin in Aspergillus species isolated from pistachio in Iran. J. Phytopathol. 156, 15-20. doi: 10.1111/j.1439-0434.2007.01312.x

Rahmani, A., Soleimany, F., Hosseini, H., and Nateghi, L. (2011). Survey on the occurrence of aflatoxins in rice from different provinces of Iran. Food Addit. Contam. Part B 4, 185-190. doi: 10.1080/19393210.2011.599865

Reddy, K. R. N., Abbas, H. K., Abel, C. A., Shier, W. T., Oliveira, C. A. F., and Raghavender, C. R. (2009). Mycotoxin contamination of commercially important agricultural commodities. Toxin Rev. 28, 154-168. doi: 10.1080/ 15569540903092050

Reddy, K. R. N., Farhana, N. I., and Salleh, B. (2011). Occurrence of Aspergillus spp. and aflatoxin B1 in Malaysian foods used for human consumption. J. Food Sci. 76, T99-T104. doi: 10.1111/j.1750-3841.2011.02133.x

Reddy, K. R. N., Salleh, B., Saad, B., Abbas, H. K., Abel, C. A., and Shier, W. T. (2010). An overview of mycotoxin contamination in foods and its implications for human health. Toxin Rev. 29, 3-26. doi: 10.3109/15569541003598553

Reiter, E., Zentek, J., and Razzazi, E. (2009). Review on sample preparation strategies and methods used for the analysis of aflatoxins in food and feed. Mol. Nutr. Food Res. 53, 508-524. doi: 10.1002/mnfr.200800145

Reiter, E. V., Vouk, F., Böhm, J., and Razzazi-Fazeli, E. (2010). Aflatoxins in ricea limited survey of products marketed in Austria. Food Control 21, 988-991. doi: 10.1016/j.foodcont.2009.12.014

Robens, J., and Cardwell, K. (2003). The costs of mycotoxin management to the USA: management of aflatoxins in the United States. J. Toxicol. Toxin Rev. 22, 139-152. doi: 10.1081/txr-120024089

Ropodi, A. I., Panagou, E. Z., and Nychas, G.-J. E. (2016). Data mining derived from food analyses using non-invasive/non-destructive analytical techniques; determination of food authenticity, quality \& safety in tandem with computer science disciplines. Trends Food Sci. Technol. 50, 11-25. doi: 10.1016/j.tifs.2016. 01.011

Rotariu, L., Lagarde, F., Jaffrezic-Renault, N., and Bala, C. (2016). Electrochemical biosensors for fast detection of food contaminants-trends and perspective. Trends Anal. Chem. 79, 80-87. doi: 10.1016/j.trac.2015.12.017 
Rui, C., He, J., Li, Y., Liang, Y., You, L., He, L., et al. (2019). Selective extraction and enrichment of aflatoxins from food samples by mesoporous silica FDU12 supported aflatoxins imprinted polymers based on surface molecularly imprinting technique. Talanta 201, 342-349. doi: 10.1016/j.talanta.2019. 04.019

Rustom, I. Y. S. (1997). Aflatoxin in food and feed: occurrence, legislation and inactivation by physical methods. Food Chem. 59, 57-67. doi: 10.1016/s03088146(96)00096-9

Rychlik, M., Humpf, H.-U., Marko, D., Dänicke, S., Mally, A., Berthiller, F., et al. (2014). Proposal of a comprehensive definition of modified and other forms of mycotoxins including "masked" mycotoxins. Mycotoxin Res. 30, 197-205. doi: 10.1007/s12550-014-0203-5

Samarajeewa, U., Sen, A. C., Fernando, S. Y., Ahmed, E. M., and Wei, C. I. (1991). Inactivation of aflatoxin B1 in corn meal, copra meal and peanuts by chlorine gas treatment. Food Chem. Toxicol. 29, 41-47. doi: 10.1016/0278-6915(91) 90061-b

Schmidt-Heydt, M., Abdel-Hadi, A., Magan, N., and Geisen, R. (2009). Complex regulation of the aflatoxin biosynthesis gene cluster of Aspergillus flavus in relation to various combinations of water activity and temperature. Int. J. Food Microbiol. 135, 231-237. doi: 10.1016/j.ijfoodmicro.2009. 07.026

Schmidt-Heydt, M., Rüfer, C. E., Abdel-Hadi, A., Magan, N., and Geisen, R. (2010). The production of aflatoxin B 1 or G 1 by Aspergillus parasiticus at various combinations of temperature and water activity is related to the ratio of aflS to aflR expression. Mycotoxin Res. 26, 241-246. doi: 10.1007/s12550-0100062-7

Schuda, P. F. (1980). "Aflatoxin Chemistry and Syntheses," in Syntheses of Natural Products. Berlin: Springer, 75-111.

Selvolini, G., Lettieri, M., Tassoni, L., Gastaldello, S., Grillo, M., Maran, C., et al. (2019). Electrochemical enzyme-linked oligonucleotide array for aflatoxin B1 detection. Talanta 203, 49-57. doi: 10.1016/j.talanta.2019.05.044

Sherif, S. O., Salama, E. E., and Abdel-Wahhab, M. A. (2009). Mycotoxins and child health: the need for health risk assessment. Int. J. Hyg. Environ. Health 212, 347-368. doi: 10.1016/j.ijheh.2008.08.002

Shrestha, S., Knapiè, M., Žibrat, U., Deleuran, L. C., and Gislum, R. (2016). Single seed near-infrared hyperspectral imaging in determining tomato (Solanum lycopersicum L.) seed quality in association with multivariate data analysis. Sens. Actuators B Chem. 237, 1027-1034. doi: 10.1016/j.snb.2016.08.170

Siche, R., Vejarano, R., Aredo, V., Velasquez, L., Saldaña, E., and Quevedo, R. (2016). Evaluation of food quality and safety with hyperspectral imaging (HSI). Food Eng. Rev. 8, 306-322. doi: 10.1007/s12393-015-9137-8

Singh, P., and Cotty, P. J. (2017). Aflatoxin contamination of dried red chilies: contrasts between the United States and Nigeria, two markets differing in regulation enforcement. Food control 80, 374-379. doi: 10.1016/j.foodcont. 2017.05.014

Soro-Yao, A. A., Brou, K., Amani, G., Thonart, P., and Djè, K. M. (2014). The use of lactic acid bacteria starter cultures during the processing of fermented cereal-based foods in West Africa: a review. Trop. Life Sci. Res. 25, 81-100.

Sulyok, M., Beed, F., Boni, S., Abass, A., Mukunzi, A., and Krska, R. (2015). Quantitation of multiple mycotoxins and cyanogenic glucosides in cassava samples from Tanzania and Rwanda by an LC-MS/MS-based multi-toxin method. Food Addit. Contam. Part A 32, 488-502. doi: 10.1080/19440049.2014. 975752

Sun, G., Wang, S., Hu, X., Su, J., Zhang, Y., Xie, Y., et al. (2011). Co-contamination of aflatoxin B1 and fumonisin B1 in food and human dietary exposure in three areas of China. Food Addit. Contam. 28, 461-470. doi: 10.1080/19440049.2010. 544678

Tabari, M., Karim, G., Ghavami, M., and Chamani, M. (2011). Method validation for aflatoxin M1 determination in yoghurt using immunoaffinity column cleanup prior to high-performance liquid chromatography. Toxicol. Ind. Health 27, 629-635. doi: 10.1177/0748233710394236

Tanaka, K., Sago, Y., Zheng, Y., Nakagawa, H., and Kushiro, M. (2007). Mycotoxins in rice. Int. J. Food Microbiol. 119, 59-66.

Tao, F., Yao, H., Hruska, Z., Burger, L. W., Rajasekaran, K., and Bhatnagar, D. (2018). Recent development of optical methods in rapid and non-destructive detection of aflatoxin and fungal contamination in agricultural products. Trends Anal. Chem. 100, 65-81. doi: 10.1016/j.trac.2017.12.017
Tchana, A., Moundipa, P., and Tchouanguep, F. (2010). Aflatoxin contamination in food and body fluids in relation to malnutrition and cancer status in Cameroon. Int. J. Environ. Res. Public Health 7, 178-188. doi: 10.3390/ijerph701 0178

Temba, M. C., Njobeh, P. B., and Kayitesi, E. (2017). Storage stability of maizegroundnut composite flours and an assessment of aflatoxin B1 and ochratoxin A contamination in flours and porridges. Food Control 71, 178-186. doi: 10.1016/j.foodcont.2016.06.033

Torović, L. (2015). Aflatoxin M1 in processed milk and infant formulae and corresponding exposure of adult population in Serbia in 2013-2014. Food Addit. Contam. Part B 8, 235-244. doi: 10.1080/19393210.2015. 1063094

Tsakiris, I. N., Tzatzarakis, M. N., Alegakis, A. K., Vlachou, M. I., Renieri, E. A., and Tsatsakis, A. M. (2013). Risk assessment scenarios of children's exposure to aflatoxin M1 residues in different milk types from the Greek market. Food Chem. Toxicol. 56, 261-265. doi: 10.1016/j.fct.2013.02.024

Udomkun, P., Wiredu, A. N., Nagle, M., Müller, J., Vanlauwe, B., and Bandyopadhyay, R. (2017). Innovative technologies to manage aflatoxins in foods and feeds and the profitability of application-A review. Food Control 76, 127-138. doi: 10.1016/j.foodcont.2017.01.008

Vidal, A., Marín, S., Sanchis, V., De Saeger, S., and De Boevre, M. (2018). Hydrolysers of modified mycotoxins in maize: $\alpha$-Amylase and cellulase induce an underestimation of the total aflatoxin content. Food Chem. 248, 86-92. doi: 10.1016/j.foodchem.2017.12.057

Wang, C., Sun, L., and Zhao, Q. (2019). A simple aptamer molecular beacon assay for rapid detection of aflatoxin B1. Chin. Chem. Lett. 30, 1017-1020. doi: 10.1016/j.cclet.2019.01.029

Wang, L., Sun, D.-W., Pu, H., and Zhu, Z. (2016). Application of hyperspectral imaging to discriminate the variety of maize seeds. Food Anal. Methods 9, 225-234. doi: 10.1007/s12161-015-0160-4

Wang, W., Heitschmidt, G. W., Windham, W. R., Feldner, P., Ni, X., and Chu, X. (2015a). Feasibility of detecting aflatoxin B1 on inoculated maize kernels surface using Vis/NIR hyperspectral imaging. J. Food Sci. 80, M116-M122. doi: 10.1111/1750-3841.12728

Wang, W., Ni, X., Lawrence, K. C., Yoon, S.-C., Heitschmidt, G. W., and Feldner, P. (2015b). Feasibility of detecting Aflatoxin B1 in single maize kernels using hyperspectral imaging. J. Food Eng. 166, 182-192. doi: 10.1016/j.jfoodeng.2015. 06.009

Williams, P. J., Geladi, P., Britz, T. J., and Manley, M. (2012). Investigation of fungal development in maize kernels using NIR hyperspectral imaging and multivariate data analysis. J. Cereal Sci. 55, 272-278. doi: 10.1016/j.jcs.2011. 12.003

Womack, E. D., Brown, A. E., and Sparks, D. L. (2014). A recent review of nonbiological remediation of aflatoxin-contaminated crops. J. Sci. Food Agric. 94, 1706-1714. doi: 10.1002/jsfa.6520

Wu, D., and Sun, D.-W. (2013). Advanced applications of hyperspectral imaging technology for food quality and safety analysis and assessment: a review-Part I: fundamentals. Innov. Food Sci. Emerg. Technol. 19, 1-14. doi: 10.1016/j.ifset. 2013.04.014

Wu, F. (2006). Mycotoxin reduction in Bt corn: potential economic, health, and regulatory impacts. Transgenic Res. 15, 277-289. doi: 10.1007/s11248-0055237-1

Wu, F. (2007). Measuring the economic impacts of Fusarium toxins in animal feeds. Anim. Feed Sci. Technol. 137, 363-374. doi: 10.1016/j.anifeedsci.2007. 06.010

Xue, Z., Zhang, Y., Yu, W., Zhang, J., Wang, J., Wan, F., et al. (2019). Recent advances in aflatoxin B1 detection based on nanotechnology and nanomaterials-A Review. Anal. Chim. Acta. 1069, 1-27. doi: 10.1016/j.aca.2019. 04.032

Yabe, K., and Nakajima, H. (2004). Enzyme reactions and genes in aflatoxin biosynthesis. Appl. Microbiol. Biotechnol. 64, 745-755. doi: 10.1007/s00253004-1566-X

Yalcin, N. F., Isik, M. K., Avci, T., Oguz, H., and Yurduseven, T. (2017). Investigation of mycotoxin residues in poultry feeds by LC MS/MS method. Ankara Univ. Vet. Fak. Derg. 64, 111-116. doi: 10.1501/vetfak_0000002784

Yang, Z.-Y., Shim, W.-B., Kim, J.-H., Park, S.-J., Kang, S.-J., Nam, B.-S., et al. (2004). Detection of aflatoxin-producing molds in Korean fermented foods and grains 
by multiplex PCR. J. Food Prot. 67, 2622-2626. doi: 10.4315/0362-028x-67.11. 2622

Yaroglu, T., Oruc, H. H., and Tayar, M. (2005). Aflatoxin M1 levels in cheese samples from some provinces of Turkey. Food Control 16, 883-885. doi: 10. 1016/j.foodcont.2004.08.001

Yu, J., Bhatnagar, D., and Ehrlich, K. C. (2002). Aflatoxin biosynthesis. Rev. Iberoam. Micol. 19, 191-200.

Zhang, X., Liu, F., He, Y., and Li, X. (2012). Application of hyperspectral imaging and chemometric calibrations for variety discrimination of maize seeds. Sensors 12, 17234-17246. doi: 10.3390/s121217234

Zhang, Z., Nie, D., Fan, K., Yang, J., Guo, W., Meng, J., et al. (2019). A systematic review of plant-conjugated masked mycotoxins: occurrence, toxicology, and metabolism. Crit. Rev. Food Sci. Nutr. 26, 1-15. doi: 10.1080/10408398.2019. 1578944
Conflict of Interest: SD employed by company SAB Miller India Ltd., Sonipat, India.

The remaining authors declare that the research was conducted in the absence of any commercial or financial relationships that could be construed as a potential conflict of interest.

Copyright (C) 2019 Mahato, Lee, Kamle, Devi, Dewangan, Kumar and Kang. This is an open-access article distributed under the terms of the Creative Commons Attribution License (CC BY). The use, distribution or reproduction in other forums is permitted, provided the original author(s) and the copyright owner(s) are credited and that the original publication in this journal is cited, in accordance with accepted academic practice. No use, distribution or reproduction is permitted which does not comply with these terms. 